Situs Jurnal : $\underline{\text { http://ejournal.stiepancasetia.ac.id/index.php/jieb }}$

Jilid 5 Nomor 2 Juli 2019

Hal $210-219$

\title{
PENGARUH BIAYA PROMOSI TERHADAP PENINGKATAN PENJUALAN BUDI DAYA IKAN OLEH KELOMPOK TANI PAKAT SASAMA DI KELURAHAN PURUK CAHU KABUPATEN MURUNG RAYA
}

\begin{abstract}
Amalia Wahyuni*
Abstract: The main objective of this research is to study and analyze (1) The influence of promotion cost which consist of advertising cost, promotion cost of sale and cost of public relation and reporting, have significant influence either partially or simultaneously. (2) The dimension of promotional cost which is greater the effect on the increase of the sale of fish cultivation by farmer group of cooperation. This research is done by quantitative method and also use analysis method with SPSS Windows For Data as a data analysis tool. Based on the result of the research, it is found that in the multiple linear regression analysis it is found that promotion cost consisting of advertising cost, sales promotion cost and public relation cost and reporting, have significant influence either partially or simultaneously to the increase of fish farming sale by farmer group of pakekan sasama.
\end{abstract}

\section{Keywords: Cost, Promotion, Sales, Cultivation}

Abstrak: Tujuan utama dalam penelitian ini adalah untuk mengkaji dan menganalisis (1) Pengaruh biaya promosi yang teridiri atas biaya periklanan, biaya promosi penjualan serta biaya hubungan masyarakat dan pemberitaan, berpengaruh signifikan baik secara parsial maupun simultan. (2) Dimensi biaya promosi mana yang lebih besar pengaruhnya terhadap peningkatan penjualan budi daya ikan oleh kelompok tani pakat sasama. Penelitian ini dilakukan dengan metode kuantitatif serta menggunakan metode analisis dengan SPSS Windows For Data sebagai sebuah alat analisis data. Berdasarkan hasil penelitian diperoleh bahwa dalam analisis regresi linier berganda didapatkan bahwa biaya promosi yang terdiri atas biaya periklanan, biaya promosi penjualan serta biaya hubungan masyarakat dan pemberitaan, berpengaruh signifikan baik secara parsial maupun simultan terhadap peningkatan penjualan budi daya ikan oleh kelompok tani pakat sasama.

Kata kunci : Biaya, Promosi, Penjualan, Budidaya

\section{Latar Belakang}

Kelompok tani pakat sasama merupakan salah satu kelompok tani tani yang ada di kelurahan puruk cahu kabupaten murung raya provinsi Kalimantan tengah. Kelurahan puruk cahu terletak tepat dipinggiran sungai barito dan memiliki curah hujan yang cukup banyak tiap tahunnya ( $4.680 \mathrm{~mm}$ ), sehingga secara geografis kelurahan puruk cahu merupakan salah satu kelurahan yang berpotensi dalam pengembangan budi daya ikan tawar disertai dengan produk lokal olahannya. Berdasarkan data dari dinas peternakan dan perikanan kabupaten murung raya, di kelurahan puruk cahu merupakan salah satu produsen yang menghasilkan dari sektor perikanan seperti ikan mas, nila, patin dan lele.

Terbatasnya bentuk olahan ikan merupakan salah satu penyebab rendahnya tingkat konsumsi ikan penduduk Indonesia. Untuk meningkatkan konsumsi ikan, perlu ditempuh 
penganekaragaman (diversifikasi) bentuk olahan ikan, terutama menuju pada produk-produk yang biasa dikonsumsi masyarakat, sehingga peluang produk untuk diterima lebih besar (Nainggolan et al. 2010). Selain pemanfaatan hasil periikanan sebagai kebutuhan konsumsi konsumen yang lebih menyukai konsumsi, tetapi juga untuk memenuhi permintaan pasar alternatif lainnya.

\begin{tabular}{|c|c|c|c|}
\hline \multirow{2}{*}{ No } & \multirow{2}{*}{ Jenis Ikan } & \multicolumn{2}{|c|}{ Tahun } \\
\hline & & 2015 & 2016 \\
\hline 1 & Ikan Mas & 1.345 .076 .76 & 1.524 .675 .98 \\
\hline 2 & Ikan Nila & $1,076.243 .78$ & 1.123 .345 .67 \\
\hline 3 & Ikan Patin & 8.678 .90 & 9.567 .78 \\
\hline 4 & Ikan Lele & 6.765 .80 & 7.890 .67 \\
\hline
\end{tabular}

Sumber: Dinas perikanan dan pertanian kabupaten murung raya 2019

Promosi memerlukan lebih dari pada sekedar memperkenalkan keunggulan-keunggulan produk, dan harga yang menarik, serta membuatnya dapat terjangkau, akan tetapi kegiatan promosi dimaksudkan untuk dapat melakukan komunikasi dengan konsumen, memperkenalkan, membujuk, mempengaruhi dan mendorong konsumen untuk membeli produk yang ditawarkan serta dapat juga digunakan untuk membangun citra pengusahaatau dalam hal ini produsen dimata konsumen.

Perusahaan-perusahaan saat ini juga telah menyadari bahwa mereka harus mengubah cara-cara mereka memasarkan dan mempromosikan produk maupun jasanya. Perusahaan tidak dapat hanya terpaku pada satu instrumen komunikasi pemasaran saja, mereka harus mengkombinasikan berbagai cara yang ada untuk mengkomunikasikan produknya (Morrisan, 2007:12). Integrasi yang terpadu dalam menggunakan instrumen promosi untuk meningkatkan nilai penjualan harus dan penting dilakukan dalam bentuk proses terpadu yang sering disebut komunikasi pemasaran terpadu atau Integrated Marketing Communications (IMC), yang mencakup upaya koordinasi dari berbagai elemen promosi dan kegiatan pemasaran lainnya (Adrienne, 1993:204).

Untuk itu, perusahaan-perusahaan harus mengalokasikan anggaran promosi ke dalam biaya promosi seefisien mungkin untuk mendapatkan nilai penjualan yang maksimal. Dalam penelitian ini, peneliti ingin menganalisis bagaimana pengaruh biaya promosi yang digunakan oleh pihak Kelompok Tani Pakat Sasama terhadap nilai penjualan produk. Dengan diketahuinya pengaruh tersebut, diharapkan dapat membantu pihak Kelompok Tani dalam mengalokasikan dana untuk promosi yang tepat sehingga diperoleh peningkatan dalam nilai penjualan hasil budi daya ikannya. Komunikasi pemasaran yang dilakukan Kelompok Tani pakat Sasama, terdiri atas tiga jenis komunikasi yang disebut promosi pemasaran antara lain, periklanan, promosi penjualan, dan hubungan masyarakat dan pemberitaan.

Menurut Angipora (2002:68) kegiatan promosi yang dilakukan sejalan dengan rencana pemasaran secara keseluruhan, serta direncanakan akan diarahkan dan dikendalikan dengan baik, diharapkan dapat berperan secara berarti dalam meningkatkan penjualan dan market share. Peningkatan volume penjualan melalui upaya pemasaran yang baik perlu ditempuh perusahaan dan untuk itu perlu diperhatikan faktor-faktor pendukungnya. Menurut Adoe (2007:47) menyatakan bahwa hal - hal yang berkaitan dengan biaya promosi dapat dipakai untuk mengukur seberapa efektif alat-alat ini dalam menghasilkan volume penjualan produk oleh perusahaan ke pasar-pasar target.

Lebih khusus lagi pengaruh faktor-faktor di atas dibuktikan riset terlebih dahulu, seperti yang dilakukan oleh : Wicaksono, 2008 (bauran komunikasi); Chasanah, 2001, Yamaguchi, 
2001 (iklan); Ducan, 2003 (hubungan masyarakat); dan Soenarmi, 2005 (promosi). Jika dikaji secara mendalam maka semua riset di atas menyimpulkan bahwa faktor bauran komunikasi yang terdiri dari periklanan, promosi penjualan, dan hubungan masyarakat dan pemberitaan mempengaruhi nilai penjualan suatu produk. Urian teori di atas, secara eksplisit dapat dijelaskan bahwa perilaku konsumen dalam membuat keputusan membeli dipengaruhi oleh perangsang pemasaran berupa bauran promosi sehingga nilai penjualan produk mengalami peningkatan.

Untuk lebih jelasnya, konsep kerangka konseptual dalam penelitian ini dapat digambarkan pada Gambar 1.

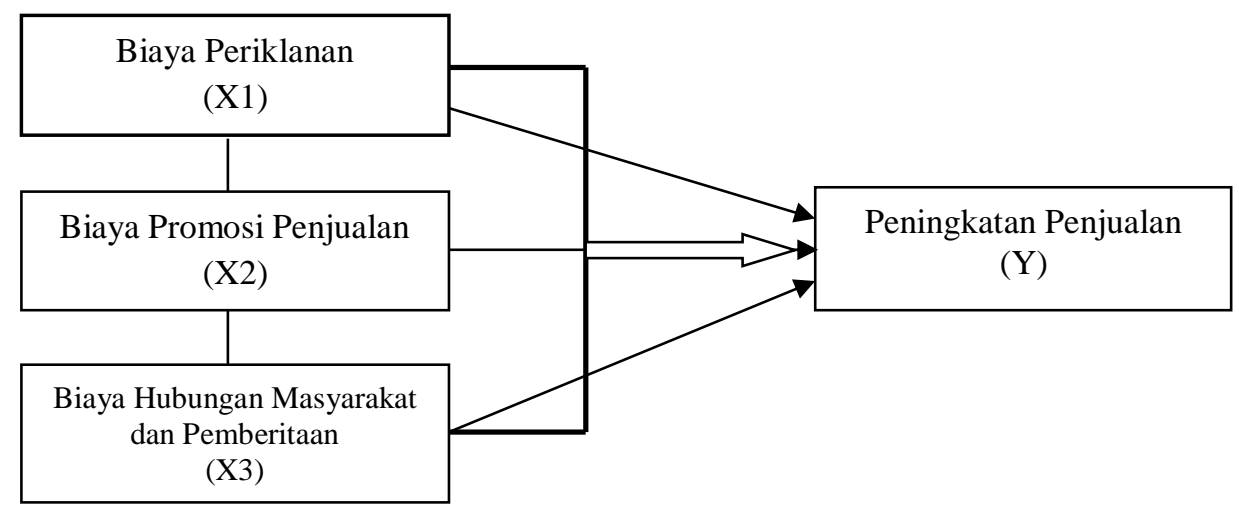

Gambar 1. Model Kerangka Konseptual Penelitian

\section{Kajian Literatur}

Pemasaran adalah suatu proses dimana produk di perjual belikan. Proses itu dapat berupa tindakan pertukaran sederhana atau dengan menggunakan mekanisme yang modern dan cukup kompleks. Untuk lebih jelasnya tentang pengertian pemasaran, maka penulis mengutip beberapa pendapat yang dikemukakan oleh beberapa ahli pemasaran. "Pemasaran adalah proses sosial dan managerial dengan nama individu dan kelompok mendapatkan upaya yang mereka butuhkan dan inginkan dengan menciptakan dan mempertukarkan produk dan nilai dengan individu dan kelompok lainnya".

Pengertian pemasaran tidak lain dari pada proses perpindahan barang dan jasa dari tangan produsen ke tangan konsumen. Atau dapat dikatakan pula bahwa pemasaran semua kegiatan usaha yang bertalian dengan arus penyerahan barang dan jasa-jasa dari produsen ke konsumen dalam arti luas, pemasaran meliputi hal-hal yang bersifat abstrak seperti asuransi, surat-surat saham dan surat-surat obligasi. American Marketing Association 1960, mengartikan pemasaran sebagai berikut: Pemasaran adalah pelaksanaan dunia usaha yang mengarahkan arus barangbarang dan jasa-jasa dari produsen ke konsumen atau pihak pemakai.

Perusahaan-perusahaan harus mengalokasikan anggaran promosi untuk kelima alat promosi antara lain periklanan, promosi penjualan, hubungan masyarakat dan pemberitaan, penjualan pribadi dan pemasaran langsung (Kotler, 2005:264). Promosi merupakan bermacam kegiatan yang dilakukan perusahaan untuk mengkomunikasikan kelebihankelebihan produknya dan membujuk pelanggan sasaran untuk membeli produk yang dihasilkan. Salah satu keputusan pemasaran tersulit adalah menentukan berapa banyak biaya yang perlu dikeluarkan untuk promosi.

Industri dan perusahaan memiliki perbedaan yang sangat besar tentang berapa banyak biaya yang dibelanjakan untuk promosi. Kegiatan promosi dimaksudkan untuk dapat melakukan komunikasi dengan konsumen, memperkenalkan, membujuk, mempengaruhi dan 
mendorong konsumen untuk membeli produk yang ditawarkan serta dapat juga digunakan untuk membangun citra perusahaan dimata konsumen. Bagi sebagian besar perusahaan, pertanyaan bukanlah apakah berkomunikasi, melainkan apa yang harus disampaikan, kepada siapa, dan seberapa sering. Promosi pemasaran terdiri dari lima cara komunikasi utama (Webster, 1992:1-17) yaitu iklan, promosi penjualan, hubungan masyarakat dan pemberitaan, penjualan pribadi, dan pemasaran langsung.

Promosi merupakan salah satu bagian dari rangkaian kegiatan pemasaran dimana dasar pengembangan kegiatan promosi adalah komunikasi. Dengan komunikasi ini seseorang, lembaga-lembaga atau masyarakat dapat saling mengadakan interaksi yang nantinya mengahadirkan sebuah proses jual beli ataupun menghadirkan konsumen yang artinya laba bagi perusahaan.

Promosi adalah usaha yang dilakukan organisasi untuk menginformasikan, membujuk, serta mengingatkan pasar terhadap organisasi itu sendiri atau produk dari organisasi. Disini, perusahaan berusaha mempengaruhi perasaan, kepercayaan, atau perilakunya. Pemberian informasi ini selain ditujukan kepada calon konsumen, juga ditujukan kepada 'intermediaries'. Membujuk disini berarti perusahaan berusaha meyakinkan konsumen untuk membeli produknya, daripada produk-produk lain walaupun fungsinya sama. Mengingatkan, berarti perusahaan berusaha meyakinkan konsumen untuk membeli produknya, dimana ini adalah proses pengulangan (karena di pasar banyak produk sejenis, dan konsumen sudah tahu.

Komunikasi pemasaran adalah kegiatan komunikasi yang dilakukan oleh penjual dengan pembelinya dan merupakan kegiatan yang membantu dalam pengambilan keputusan di bidang pemasaran serta mengarahkan pertukaran agar lebih memuaskan dengan cara menyadarkan semua pihak untuk berbuat lebih baik. Jadi komunikasi pemasaran itu merupakan pertukaran informasi dua arah antara pihak-pihak atau lembaga-lembaga yang terlibat dalam pemasaran. Promosi adalah komunikasi yang persuasif, mengajak, membujuk dan meyakinkan. Ciri dari komunikasi yang persuasif adalah: ada komunikator yang mengatur berita dan cara penyampaiannya mendapatkan akibat tertentu bagi si penerima (target pendengar). 8 Pengertian promosi sebagai berikut : "Promosi adalah arus informasi yang dibuat untuk mengarahkan seseorang atau organisasi kepada tindakan yang menciptakan pertukaran dalam pemasaran.

Iklan, setiap bentuk presentasi yang bukan dilakukan orang dan promosi gagasan, barang dan jasa oleh sponsor yang telah ditentukan. Periklanan adalah komunikasi non individu dengan jumlah biaya, melalui berbagai media yang dilakukan oleh perusahaan, lembaga nonlaba serta individu-individu. Periklanan sebagai salah satu kegiatan promosi memiliki beberapa fungsi antara lain :

1. Memberikan informasi

2. Membujuk atau mempengaruhi

3. Menciptakan kesan/image

4. Memuaskan keinginan

5. Periklanan merupakan alat komunikasi

Iklan adalah segala bentuk presentasi non-pribadi dan promosi gagasan, barang atau jasa oleh sponsor tertentu yang harus dibayar (Kotler (2005:277). Menurut Fandi Tjiptono (2008:225) menyatakan bahwa iklan merupakan salah satu bentuk promosi yang paling banyak digunakan perusahaan dalam mempromosikan produknya. Selain itu, menurut Machfoedz (2010:139) bahwa iklan adalah segala bentuk penyajian informasi dan promosi secara tidak langsung yang dilakukan oleh sponsor untuk menawarkan ide, barang atau jasa.

Perusahaan tidak hanya harus berhubungan secara konstruktif dengan pelanggan, pemasok dan penyalur, melainkan juga harus berhubungan dengan sejumlah besar masyarakat yang berkepentingan (Kotler, 2005:306). Masyarakat (publik) adalah setiap kelompok yang 
memiliki kepentingan dalam atau pengaruh terhadap kemampuan suatu perusahaan mencapai tujuannya saat ini atau masa yang mendatang. Hubungan masyarakat (public relation) meliputi berbagai program yang dirancang untuk mempromosikan atau melindungi citra perusahaan atau masing-masing produknya.

Suatu perusahaan akan mampu bertahan apabila perusahaan tersebut dapat memasarkan barang dan jasa yang dihasilkannya yang sesuai dengan kebutuhan dan diterima oleh konsumen (masyarakat) dan harga yang ditawarkan oleh perusahaan sesuai dengan permintaan konsumen (masyarakat) itu sendiri. Menurut Stanton (2001 : 16) mengatakan bahwa Penjualan adalah suatu usaha untuk membujuk konsumen membeli produknya agar sesuai dengan supply yang diajukan. Lain halnya dengan Kotler (2007 : 16-17) mengatakan bahwa Penjualan adalah tujuan inti suatu perusahaan, dimana seorang penjual berusaha membuat apa yang pasar inginkan dan atau apa yang dapat kita jual bukan menjual apa yang kita hasilkan.

\section{Metode Penelitian}

Pendekatan yang digunakan dalam penelitian ini adalah dengan pendekatan survei yaitu penelitian yang mengambil sampel dari populasi dan menggunakan kuesioner sebagai alat pengumpulan data yang pokok. Untuk memudahkan justifikasi terhadap persepsi karyawan digunakan skala Likert 5 poin.

Objek dalam penelitian ini adalah Kelompok Tani Pakat Sasama, Kelurahan Puruk Cahu, Kabupaten Murung raya, Kalimantan Tengah. Yang menjadi populasi dalam penelitian ini adalah semua konsumen Kelompok Tani Pakat Sasama. Menurut Arikunto (1998 : 120), "Jika populasinya kurang dari 100 maka sampel yang diambil adalah seluruh konsumen, tetapi apabila jumlah populasi lebih dari 100 maka sampel yang diambil dikalikan minimal 10\% dari jumlah populasi tersebut". Dalam penelitian ini sampel ditentukan sebanyak 100 responden. Teknik sampel yang digunakan dalam penelita ini Accidental Random Sampling, pengambilan sampel secara acak terhadap responden yang paling mudah ditemui dan bersedia berpartisipasi dalam pengisian kuisioner.

Teknik analisis data yang digunakan dalam penelitian ini menggunakan regresi linear berganda dengan bantuan program SPSS versi 17.0 dengan persamaan regresi:

$\mathrm{Y}=\mathrm{a}+\mathrm{b} 1 \mathrm{X} 1+\mathrm{b} 2 \mathrm{X} 2+\mathrm{b} 3 \mathrm{X} 3$

\section{Keterangan :}

$\mathrm{Y}=$ Jumlah nilai penjualan

$\mathrm{a}=$ Konstanta

b1 $=$ Koefisien regresi dari biaya periklanan

b2 $=$ Koefisien regresi dari biaya promosi penjualan

b3 = Koefisien regresi dari biaya hubungan masyarakat dan pemberitaan

$\mathrm{X} 1=$ Variabel biaya periklanan

$\mathrm{X} 2=$ Variabel biaya promosi penjualan

$\mathrm{X} 3$ = Variabel biaya hubungan masyarakat dan pemberitaan

Sebelum dilakukan pengujian dengan analisis regresi, data penelitian diuji dengan uji asumsi klasik yang terdiri dari : uji normalitas, uji heterokedastisitas, dan uji multikolonieritas. Kemudian untuk pengujian hipotesis secara simultan menggunakan Uji F, dan untuk pengujian hipotesis secara parsial menggunakan Uji t. Sedangkan untuk menentukan variabel yang paling dominan mempengaruhi nilai penjualan produk menggunakan nilai standardized coefficient beta. 


\section{Hasil Penelitian dan Pembahasan}

Dari hasil pengolahan data dengan komputer diperoleh koefisien regresi seperti dalam tabel 2 .

Tabel 2. Koefisien Regresi Linear Berganda

\begin{tabular}{|c|c|c|c|c|c|c|}
\hline \multicolumn{7}{|c|}{ Coefficients(a) } \\
\hline & & \multicolumn{2}{|c|}{$\begin{array}{l}\text { Unstandardized } \\
\text { Coefficients }\end{array}$} & \multirow{2}{*}{$\begin{array}{c}\begin{array}{c}\text { Standardized } \\
\text { Coefficients }\end{array} \\
\text { Beta }\end{array}$} & \multirow[t]{2}{*}{$t$} & \multirow[t]{2}{*}{ Sig. } \\
\hline & & $\mathrm{B}$ & Std. Error & & & \\
\hline 1 & (Constant) & .548 & .405 & & -1.351 & .180 \\
\hline & PERIKLANAN & .510 & .127 & .402 & 4.031 & .000 \\
\hline & $\begin{array}{l}\text { PROMOSI } \\
\text { PENJUALAN }\end{array}$ & .279 & .161 & .183 & 1.734 & .086 \\
\hline & PEMBERITAAN & .328 & .158 & .270 & 2.076 & .041 \\
\hline
\end{tabular}

Sumber: Data Primer yang sudah diolah 2019.

Berdasarkap pada tabel 2, maka persamaan Regresi yang terbentuk dari hasil analisis regresi berganda tersebut adalah sebagai berikut:

$$
\mathrm{Y}=0,548+0,510 \times 1+0,279 \times 2+0,328 \times 3+e
$$

Hasil dari analisis tersebut dapat diinterprestasikan sebagai berikut:

$\mathrm{a}=0,548$ artinya bahwa variabel Biaya promosi yang terdiri atas Biaya Periklanan, Biaya Promosi Penjualan dan Biaya Pemberitaan sama dengan nol maka Tingkat Penjualan akan naik sebesar 0,548 satuan.

b1=0,510, artinya bahwa apabila Kelompok Tani Pakat Sasama memperhatikan variabel Biaya Periklanan (X1), maka maka Tingkat Penjualan akan naik sebesar 0,510 satuan, sedangkan variabel lain konstan.

b2=0,279, artinya bahwa apabila Kelompok Tani Pakat Sasama memperhatikan variabel Biaya Promosi (X2), maka Tingkat Penjualan akan naik sebesar 0,017 satuan, sedangkan variabel lain konstan.

b3 $=0,328, \quad$ artinya bahwa apabila Kelompok Tani Pakat Sasama memperhatikan variabel Biaya Pemberitaan (X3), maka Tingkat Penjualan akan naik sebesar 0,328 satuan, sedangkan variabel lain konstan.

Teknik uji $\mathrm{F}$ yang dipergunakan yaitu dengan membandingkan antara $\mathrm{F}$ hitung dengan $\mathrm{F}$ tabel, jika $\mathrm{F}$ hitung lebih besar dari $\mathrm{F}$ tabel maka keputusannya adalah $\mathrm{H}_{\mathrm{o}}$ dan $\mathrm{H}_{\mathrm{a}}$ diterima. Dengan tingkat keyakinan $95 \%$ dan derajat kebebasan $(\mathrm{k}-1)(\mathrm{n}-\mathrm{k})$ maka tabel untuk F $(0,05)(4)$ $(97)=2,3092$. Perbandingan antara $F$ hitung dengan $F$ tabel dapat dilihat dalam tabel 3 . Dari tabel 3 diatas ternyata $\mathrm{F}$ hitung lebih besar (47.498) dari $\mathrm{F}$ tabel (2,3092), sehingga keputusannya adalah menolak $\mathrm{H}_{0}$ dan menerima $\mathrm{H}_{\mathrm{a}}$ yang artinya variabel $\mathrm{X} 1, \mathrm{X} 2$ dan $\mathrm{X} 3$ secara bersama-sama berpengaruh pada Tingkat Penjualan. 
Tabel 3. Perbandingan F Hitung dan F Tabel

\begin{tabular}{ccc}
\hline F Hitung & F Tabel & Sig. \\
\hline 47.498 & 2,3092 & 0,000 \\
\hline
\end{tabular}

Sumber: Data Primer yang sudah diolah 2019.

Teknik uji $\mathrm{T}$ yang dilakukan yaitu dengan melihat nilai $\mathrm{T}$ signifikan pada hasil pengolahan data melalui SPSS. Dalam penelitian ini $\alpha$ yang digunakan yaitu sebesar $5 \%(0,05)$. Keputusannya, jika nilai T signifikan $<$ terhadap $\alpha$ maka $\mathrm{H}_{0}$ akan ditolak dan menerima $\mathrm{H}_{\mathrm{a}}$.

Tabel 4. Rangkuman Nilai T Signifikan

\begin{tabular}{llrrrrr}
\hline Model & \multicolumn{2}{c}{$\begin{array}{c}\text { Unstandardized } \\
\text { Coefficients }\end{array}$} & $\begin{array}{c}\text { Standardized } \\
\text { Coefficients }\end{array}$ & $\mathrm{t}$ & Sig. \\
\hline \multicolumn{1}{c}{ B } & \multicolumn{2}{c}{ Std. Error } & Beta & & \\
\hline 1 & (Constant) & .548 & .405 & & -1.351 & .180 \\
\hline & PERIKLANAN & .510 & .127 & .402 & 4.031 & .000 \\
\hline & PROMOSI PENJUALAN & .279 & .161 & .183 & 1.734 & .086 \\
\hline & PEMBERITAAN & .328 & .158 & .270 & 2.076 & .041 \\
\hline
\end{tabular}

Sumber: Data Primer yang sudah diolah 2019

Dari hasil rangkuman nilai T signifikan pada tabel 4 diatas terlihat bahwa, nilai signifikan $\mathrm{T}$ untuk $\mathrm{X} 1=0,000$, artinya $\mathrm{X} 1$ (Biaya Periklanan) signifikan dalam mempengaruhi tingkat penjualan. Jadi variabel X1 (Biaya Periklanan) signifikan dalam mempengaruhi Y (Tingkat Penjualan) atau $\mathrm{H0}$ ditolak dan Ha diterima.

Untuk Variabel X2 (Biaya promosi) nilai signifikan T lebih besar dari 5\% yaitu 0,086 . Untuk Variabel X3 (Biaya Pemberitaan) nilai signifikan T lebih besar dari 5\% yaitu 0,041. Jadi variabel X2 dan X3 signifikan dalam mempengaruhi Y (Tingkat Penjualan) atau H0 ditolak dan Ha diterima.

Sutrisno Hadi (1996) dalam penjelasannya mengenai kaidah uji hipotesis penelitian, jika hasil peluang ralat $(\mathrm{p})<0,15$ hasilnya dikategorikan cukup signifikan artinya $\mathrm{H} 0$ ditolak dan Ha diterima.

Koefisien determinasi menunjukan besarnya kemampuan semua variabel bebas dalam menjelaskan variabel terikatnya. Koefisien determinasi ini dihitung dengan mengkuadratkan koefisien korelasi (R). Hasil perhitungan dapat dilihat pada tabel 5.

Tabel 5. Hasil Uji Koefisien Determinasi

\begin{tabular}{cccc}
\hline $\mathrm{R}$ & $\mathrm{R}$ Square & Adjusted R Square & Std. Error Of the Estimate \\
\hline 0,773 & 0,597 & 0,585 & 0,570 \\
\hline
\end{tabular}

Sumber: Data yang Sudah Diolah

Nilai $\mathrm{R}^{2}$ yang tersaji pada tabel diatas menunjukan nilai 0,597 atau $59,7 \%$. Hal ini dapat diartikan bahwa sebanyak 59,7\% Tingkat Penjualan dijelaskan oleh variabel Promosi yang terdiri dari biaya periklanan. Biaya promosi dan biaya periklanan. Sedangkan sisanya sebesar 40,3\% dijelaskan oleh variabel lain diluar variabel Promosi yang terdiri dari biaya periklanan. Biaya promosi dan biaya periklanan.

Dari hasil analisis yang dilakukan, diperoleh bahwa variabel Promosi yang terdiri dari biaya periklanan, Biaya promosi dan biaya periklanan berpengaruh secara siginifikan dan perubahannya berubah searah dengan tingkat penjualan. Artinya jika tingkat biaya periklanan, 
Biaya promosi dan biaya periklanan yang dilakukan makin tinggi, maka mengakibatkan makin tinggi juga tingkat penjualan hasil budidaya ikannya.

Persamaan regresi yang didapat dari hasil analisis tersebut adalah:

$$
\mathrm{Y}=0,548+0,510 \mathrm{X} 1+0,279 \times 2+0,328 \times 3+e
$$

Untuk melihat dominasi pengaruh dari variabel bebas terhadap variabel terikatnya, maka bisa dilihat koefisien beta (koefisien regresi baku). Nilai koefisien regresi baku antar variabel bebas dapat dibandingkan, karena nilainya telah distandarisasi sehingga variabel bebas (promosi) yang memiliki koefisien regresi baku yang lebih besar, berarti akan memberi pengaruh yang lebih besar pula pada variabel terikatnya.

Tabel 6. Koefisien Beta $(B)$

\begin{tabular}{llrrrrr}
\hline Model & & \multicolumn{2}{c}{$\begin{array}{c}\text { Unstandardized } \\
\text { Coefficients }\end{array}$} & $\begin{array}{c}\text { Standardized } \\
\text { Coefficients }\end{array}$ & t & Sig. \\
\hline & & B & Std. Error & Beta & & \\
\hline 1 & (Constant) & .548 & .405 & & -1.351 & .180 \\
\hline & PERIKLANAN & .510 & .127 & .402 & 4.031 & .000 \\
\hline & PROMOSI PENJUALAN & .279 & .161 & .183 & 1.734 & .086 \\
\hline & PEMBERITAAN & .328 & .158 & .270 & 2.076 & .041 \\
\hline
\end{tabular}

Hasil pengolahan data penelitian ini, ternyata variabel bebas yang memiliki beta terbesar adalah variabel Periklanan (X1) yaitu sebesar 0,548. Oleh karena itu dapat dikatakan bahwa variabel promosi yang memiliki pengaruh terbesar terhadap tingkat penjualan adalah variabel X1 (periklanan) yaitu dengan koefisien regresi baku sebesar 0,548. Hasil pembuktian hipotesa pertama (H1) yaitu keputusannya menolak $\mathrm{H}_{0}$ dan menerima $\mathrm{H}_{\mathrm{a}}$ yang artinya uji $\mathrm{F}$ terhadap persamaan regresi yang diperoleh dari penelitian ini menunjukan hasil bahwa, secara bersama-sama ketiga variabel promosi yakni biaya periklanan,, Biaya promosi dan biaya periklanan berpengaruh terhadap tingkat penjualan hasil budidaya ikan oleh Kelompok Tani Pakat Sasama.

Implikasi hasil uji F bagi Kelompok Tani Pakat Sasama adalah jika Kelompok Tani Pakat Sasama akan meningkatkan promosi perlu menekankan pada tiga faktor tersebut yaitu berturut-turut biaya periklanan,, Biaya promosi dan biaya periklanan. Hal ini harus dilakukan secara terus menerus (continues improvement) dalam usaha untuk persaingan (kompetisi) yang semakin ketat antar kelompok tani, khususnya hasil budidaya ikan.

Selain uraian diatas, dari uji $\mathrm{T}$ yang dilakukan guna pengujian $\mathrm{H} 2, \mathrm{H} 3$ dan $\mathrm{H} 4$, hasil yang diperoleh adalah sebagai berikut:

1. Untuk variabel biaya periklanan (X1) pada $\mathrm{H} 2$ hasilnya signifikan karena $\mathrm{T}$ signifikannya lebih kecil dari 5\% yaitu sebesar 0,000 sehingga $\mathrm{H}_{0}$ ditolak dan $\mathrm{H}_{\mathrm{a}}$ diterima, artinya variabel biaya periklanan (X1) signifikan dalam mempengaruhi tingkat penjualan hasil budidaya ikan oleh kelompok tani pakat sasama.

2. Untuk Variabel Biaya Promosi (X2) nilai signifikan T lebih besar dari 5\% yaitu 0,086.

3. Untuk Variabel Biaya Periklanan (X3) nilai signifikan T lebih besar dari 5\% yaitu 0,041.

Implikasinya adalah jika Kelompok Tani Pakat Sasama ingin meningkatkan hasil penjualan melalui peningkatan berbagai macam biaya promosi, maka harus memberikan perhatian yang lebih besar terhadap ketiga faktor promosi yang telah disebut diatas, tentu saja dengan penekanan yang berbeda, misal untuk Biaya Periklanan (X1) yang perlu ditingkat lebih baik adalah adanya iklan-iklan yang dipasang di media cetak atau elektronik. Untuk Biaya promosi (X2) yang perlu ditingkatkan adalah penyebaran brosur atau spanduk-spanduk yang 
dinilai lebih efektif. Untuk pemberitaan (X3) perhatian yang lebih harus diberikan pada kecepatan bahwa sampainya berita tentang hasil dan harga ikan sampai ke konsumen.

Untuk mendukung keterangan diatas dapat juga kita lihat hasil $\mathrm{R}^{2}$ (Koefisien Determinasi) Regresi yaitu sebesar 0,597 artinya sebesar 59,7\% dapat dijelaskan oleh variabel Promosi yang terdiri dari biaya periklanan,, Biaya promosi dan biaya periklanan. Sisanya sebesar 40,3\% tingkat penjualan hasil budidaya ikan dijelaskan oleh variabel lain yang tidak ada dalam model. Jadi model yang digunakan dianggap cukup signifikan.

\section{Kesimpulan}

Simpulan dari hasil pembahasan penelitian adalah Diketehui bahwa variabel Promosi berpengaruh secara signifikan dan positif terhadap Tingkat penjualan hasil budidaya ikan oleh Kelompok Tani Pakat Sasama. Variabel Periklanan (X1) berpengaruh secara signifikan dan positif terhadap Tingkat penjualan hasil budidaya ikan oleh Kelompok Tani Pakat Sasama. Variabel Biaya Promosi (X2) berpengaruh secara signifikan dan positif terhadap Tingkat penjualan hasil budidaya ikan oleh Kelompok Tani Pakat Sasama. Variabel Periklanan (X3) berpengaruh secara signifikan dan positif terhadap Tingkat penjualan hasil budidaya ikan oleh Kelompok Tani Pakat Sasama.

Adapun saran yang perlu direkomendasikan dalam penelitian ini adalah perlu memfokuskan hasil penelitian yang memilki pengaruh signifikan yaitu: Unsur Promosi Kelompok Tani Pakat Sasama yang paling mendesak untuk diperbaiki adalah Periklanan, karena unsur inilah yang paling besar pengaruhnya terhadap Tingkat Penjualan, jika tidak maka pihak Kelompok Tani Pakat Sasama akan mengalami penurunan jumlah pendapatan atau omset yang terus-menerus menurun. Untuk dapat meningkatkan Periklanan, Pihak Kelompok Tani akat Sasama dapat melakukan usaha-usaha sebagai berikut; penigkatan dari segi efektivitasnya sebuah iklan yang dilakukan seperti melakukan pembuatan spanduk, brosur serta cepatnya penyampaian pemberitaan promosi yang dilakukan oleh Kelompok Tani Pakat Sasama ke konsumen.

\section{DAFTAR PUSTAKA}

Angipora, P.M. 2002. Dasar-Dasar Pemasaran. Edisi I, Cetakan I. Jakarta : PT Raja Grafindo Persada.

Angipora, P.M. 2009. Dasar-Dasar Pemasaran. Edisi Kedua. Jakarta : PT Raja Grafindo Persada.

Adoe, K.K. 2007. Analisis Pengaruh Biaya Promosi Penjualan Terhadap Volume Penjualan Produk Tenun Ikat Pada Sentra Tenun Ikat Ina Ndao Kupang. Jurnal Mitra Vol. XIII, No. 3, pp. 370-379.

Andriyan, R., M. Hubeis dan A. Munandar. 2011. Kelayakan dan Strategi Pengembangan Usaha Kelompok Pembudidauaan Ikan Melalui Program Replika Skim Modal Kerja di Kelompok Tani Ikan Mekar Jaya

Boyd, H.W. 2003. Manajemen Pemasaran: Suatu Pendekatan Strategis dengan orientasi Global, Alih bahasa Imam Nurmawan. Jakarta : Erlangga.

Baharudin, M. 2005. "Variabel-Variabel Dominan Yang Berpengaruh Terhadap Kebijakan Promosi Kendaraan Roda Empat di Indonesia". Available from http://www.malang.ac.id/jurnal/fe/ips/2003a.htm.

Chasanah, U. 2001. "Analisis Efektivitas Iklan Rinso, Soklin, dan Attack dengan Menggunakan Consumer Decetion Model (CDM)". Yogyakarta : STIE

Djarwanto, PS. Dan Pangestu Subagyo, 1997. Statistik Induktif. 
Ducan, T. 1993. "A Study of How Manufacturers and service Companies Perceive and Use Marketing Public Relations". Journal of Economic Psychology, Vol. 8 No. 12. Muncie. IN: Ball State University, pp. 4-8.

David, F.R. 2004. Konsep Manajemen Strategis. PT. Prenhallindo, Jakarta.

Dinas Peternakan, Perikanan dan Kelautan Kabupaten Cianjur. 2012. Laporan: Produksi Benih Ikan. Unit Pembenihan Rakyat Kabupaten Cianjur, Cianjur

Ghozali, Imam. 2005. Aplikasi Analisis Multivariate dengan Program SPSS. Semarang : Badan Penerbit Undip.

Handoko, T Hani. 1997. Manajemen Edisi II. Yogyakarta : BPFE.

Kotler, Philip. 1999. Manajemen Pemasaran : Analisis Perencanaan, Implementasi dan Kontrol. Edisi 9, Jilid I Jakarta: PT Prohalindo.

Kotler, Philip. 2007. Manajemen Pemasaran : Analisis Perencanaan, Implementasi dan Kontrol. Edisi 9, Cet.1 Jakarta: PT. Macana Jaya Cemerlang.

Katke, K. (2007). The Impact of Television Advertising on Child Health \& Family Spending. International Marketing Conference on Marketing \& Society. Retrieved on Dated: 1004-2009 from http://www.itu.int/ITUD/ict/newslog/content/binary/20-2008jpg.

Kotler, P. 2000. Manajemen Pemasaran, Marketing Manajemen, Analisis Perencanaan, Implementasi dan Pengendalian. Edisi Bahasa Indonesia. Jakarta : Prehallindo.

Kotler, P. 2005. Manajemen Pemasaran. Jilid 1, Jakarta : PT Indeks Kelompok Gramedia.

Kotler, P. 2006. According To Kotler Tokoh Paling Kompeten Dalam Pemasaran Menjawab Pertanyaan Anda. Jakarta : PT Bhuana Ilmu Populer Kelompok Gramedia.

Kotler, P. 2007. Manajemen Pemasaran. Analisis Perencanaan Implementasi dan Kontrol. Jakarta : PT Prenhallindo.

Kotler, P. and Amstrong, G. 2008. Prinsip-prinsip Pemasaran, Edisi ke-12, Jilid I. Jakarta : Erlangga

Morissan. 2007. Periklanan Komunikasi Pemasaran Terpadu. Jakarta : Penerbit Ramdina Prakasa.

Sugiyono. 2005. Statistika Untuk Penelitian. Bandung: Alfabeta

Sunyoto, Danny. 2009. Analisa Regresi dan Uji Hipotesis. Yogyakarta: Media Pressindo.

Wibowo. 2006. Manajemen Perubahan. Jakarta : Raja Grafindo Persada.Wicaksana, I.N.G. 2008. "Pengaruh Biaya Promosi Terhadap Nilai Penjualan Kamar Pada Hotel Bakung's Beach di Kuta, Badung" (tesis). Denpasar : Program Pasca Sarjana Fakultas Ekonomi Universitas Udayana. 